\title{
Energy Recovery Potential of Obomkpa Coal
}

\author{
Bemgba B. Nyakuma ${ }^{1,2^{*}}$ \\ ${ }^{1}$ Hydrogen and Fuel Cell Lab., Institute of Future Energy, Universiti \\ Teknologi Malaysia, 81310 Skudai, Johor, Malaysia. \\ ${ }^{2}$ School of Chemical and Energy Engineering, Faculty of Engineering, \\ Universiti Teknologi Malaysia, 81310 Skudai, Johor, Malaysia.
}

*Correspondence Email: bbnyax1@gmail.com, bemgba.nyakuma@utm.my

\begin{abstract}
This study presents preliminary findings on the physicochemical, calorific, and thermal properties of a newly discovered coal from Obomkpa town in Aniocha-North Local Government Area of Delta State in Nigeria. The Obomkpa (BMK) coal sample was subjected to fuel characterisation through ASTM standards and techniques for determining elemental, proximate, and calorific coal properties. The results indicated that BMK coal contains high carbon, oxygen, volatile matter, fixed carbon, and ash. The higher heating value of BMK was $19.66 \mathrm{MJ} / \mathrm{kg}$, which indicates it could be ranked as either lignite $\mathrm{A}$ or subbituminous $\mathrm{C}$ coal. The thermal properties indicated that BMK experienced significant mass loss $\left(\mathrm{M}_{\mathrm{L}}\right)$ under oxidative (combustion) and nonoxidative (pyrolysis) conditions due to thermal degradation of organic rock macerals (inertinite and vitrinite). Furthermore, BMK experienced mass loss $\left(\mathrm{M}_{\mathrm{L}}=59.27 \%-76.56 \%\right)$ along with residual mass $\left(\mathrm{R}_{\mathrm{M}}=23.44-40.73 \%\right)$ under oxidative (combustion) and non-oxidative (pyrolysis) conditions. Thermal degradation occurred in three (3) stages; drying $\left(30{ }^{\circ} \mathrm{C}\right.$ to $\left.200{ }^{\circ} \mathrm{C}\right)$,
\end{abstract}


devolatilization $\left(200{ }^{\circ} \mathrm{C}-500{ }^{\circ} \mathrm{C}\right.$ and $\left.600{ }^{\circ} \mathrm{C}\right)$, and lastly, coke degradation and ash formation. Furthermore, the DTG peaks for the drying and devolatilization of BMK during the oxidative (combustion) process occurred at lower temperatures compared to the non-oxidative (pyrolysis) process. Hence, the results submit oxidative (combustion) is a more thermally efficient process compared to the non-oxidative (pyrolysis) process. Lastly, the findings indicate BMK is a potential feedstock material for future coal power generation, steel, iron ore or cement production.

Keywords: Obomkpa, Macerals, Vitrinite, Coal, Combustion, Pyrolysis, Nigeria.

\section{Introduction}

Coal is an organic, combustible, and sedimentary rock formed from several years of metamorphic reactions on the plant and animal remains in the earth's crust (Speight, 2013). As a result, coal is considered an important fossil fuel with high carbon, fixed carbon, and higher heating values with various potential applications (Miller, 2016). Over the years, coal has become an integral part of the global energy mix due to its low processing costs, widespread availability, and geographically distribution on the planet (IEA, 2018). Currently, coal accounts for 38-41\% of all electricity generated globally (BP, 2018). Coal-fired electricity is typically generated through pulverised coal combustion (PCC), which utilises various ranks of coal (Nimmo et al., 2010; AlAbbas et al., 2013; Dai et al., 2015).

Over the years, numerous deposits of coal have been discovered around the globe particularly in developing countries. Most notably, there are numerous reports of new coal deposits in Nigeria (Nyakuma et al., 2016; Nyakuma, 2016; Nyakuma et al., 2018a), which is the largest economy and most populous nation in Africa. The utilization of coal for power generation presents 
significant opportunities for rapid socio-economic growth, infrastructural development, and poverty alleviation (Musa, 2010; Oseni, 2011; Oboirien et al., 2018). Currently, Nigeria experiences perennial power cuts and load shedding due to numerous challenges such as low generation along with inefficient distribution, and transmission (Odior and Oyawale, 2012; Odior and Omadudu, 2013). Hence, the underlying problems of power generation highlighted in the literature (Oyedepo, 2014; Ocheri, 2017; Denloye and Akinola, 2017) could be potentially addressed through coal utilization for power generation in Nigeria.

Conversely, the utilization of coal for electric power generation requires comprehensive data on the fuel properties, emissions profile, life cycle, environmental impact, and engineering economics among others. Typically, the physicochemical, calorific, and thermal properties of coals avail designers, engineers, policy/decision-makers with valuable data required for the planning, design, and development of coal-fired power plants. In addition, the outlined properties of coal provide insights into the thermal degradation behaviour, emissions profile, and potential environmental impact during energy recovery and electricity generation in power plants. However, the data on various Nigeria coals is limited to the geological, geochemical, petrographic, petrologic, sedimentology, and mineralogical properties as reported in the literature (Ayinla et al., 2017; Ogala, 2018; Akinyemi et al., 2020).

Therefore, this study seeks to present preliminary data on the fuel properties of a newly discovered coal from Obomkpa (BMK) town in Aniocha-North Local Government Area of Delta State in Nigeria. Consequently, the physicochemical and calorific properties of BMK coal were characterised through selected ASTM standards, techniques and equipment. The thermal properties were examined under a non-isothermal program to simulate the flash (high heating rates) conditions typically observed in large scale coal conversion in coal-fired power plants. 


\section{Experimental}

This section presents the materials and methods employed to examine the fuel and energetic properties of BMK coal. The coal sample was obtained from Obomkpa town in Aniocha-North Local Government Area of Delta State in Nigeria. The sampling and sample preparation methods are presented in the previous study (Nyakuma et al., 2018c).

\subsection{Physicochemical Analysis}

The physicochemical analysis of BMK was examined through ultimate, proximate, and calorific analyses. Firstly, the pulverised BMK of particle size $<250 \mu \mathrm{m}$ was examined through an elemental analyser (vario MACRO Cube, Germany) to determine its carbon (C), hydrogen (H), nitrogen $(\mathrm{N})$, and sulphur $(\mathrm{S})$ compositions based on the ASTM standard D5373. Subsequently, the proximate analysis was determined by thermogravimetric analysis (TGA) based on the procedure of Donahue and Rais (2009). The moisture (MC) and volatile matter (VM) contents were determined at $110{ }^{\circ} \mathrm{C}$ and $900{ }^{\circ} \mathrm{C}$, respectively under nitrogen $\left(\mathrm{N}_{2}\right)$ atmosphere, whereas the ash content (AC) was determined in air atmosphere at $900^{\circ} \mathrm{C}$. The fixed carbon (FC) content was subsequently determined by difference from the sum of MC, VM, and AC previously determined by TGA. Lastly, the calorific value was determined by bomb calorimetry through the isoperibol bomb calorimeter (IKA C200, USA). Each test was performed in duplicate to ensure the reliability and accuracy of the averaged measurements presented in Table 1.

\subsection{Thermal Analysis}

The thermal analysis and energy recovery potential of BMK were investigated by thermogravimetric (TG) analysis. For each test run, 17-20 mg of BMK was weighed in alumina 
crucible before transferring to the TG analyser (Shimadzu TG-50, Japan) for thermal analysis. Next, the sample was heated under the selected non-isothermal heating program from room temperature or $25^{\circ} \mathrm{C}$ to $900{ }^{\circ} \mathrm{C}$ based on the flash heating rate of $50{ }^{\circ} \mathrm{C} / \mathrm{min}$. For the flash oxidative (combustion) conditions, the sample was heated under air atmosphere (flow rate $=20 \mathrm{~mL} / \mathrm{min}$ ), whereas the flash non-oxidative (pyrolysis) process was performed under nitrogen $\left(\mathrm{N}_{2}\right)$ (flow rate $=20 \mathrm{~mL} / \mathrm{min}$ ). After the processes were completed, the raw thermogram (.tad) data were analysed on the thermal analysis software (Shimadzu Workstation TA-60WS, Japan). The resulting mass loss and derivative mass loss data were retrieved and plotted against temperature to obtain the TG, DTG, conversion plots presented in Figures 1-3.

\subsection{Temperature Profile Analysis}

The thermal degradation of BMK was further examined through temperature profile analysis. Hence, the temperature profile characteristics (TPC) were deduced for the thermal degradation of BMK under oxidative (combustion) and non-oxidative (pyrolysis) TG conditions. For this study, the TPCs deduced from the TA-60WS software were; the onset or ignition temperature $\left(T_{\text {ons }}\right)$, midpoint temperature $\left(T_{m i d}\right)$, burnout or offset temperature $\left(T_{o f f}\right)$, mass loss $\left(\mathrm{M}_{\mathrm{L}}\right.$, $\%)$ and residual mass $\left(\mathrm{R}_{\mathrm{M}}, \%\right)$ from the $\mathrm{TG}$ plots in Figure 1. However, the drying and devolatilization peak temperatures were deduced from the DTG plots in Figure 3. Based on the TPCs, the thermal degradation behaviour of BMK was examined. This approach has been successfully employed by numerous researchers to describe the distinct degradation characteristics of thermally decomposing biomass and coal samples (Lopez-Velazquez et al., 2013; Nyakuma et al., 2015; Maia and de Morais, 2016; Cai et al., 2017). 


\section{Results and Discussion}

The fuel properties and energy recovery potential of BMK coal are presented based on its ultimate, proximate, calorific, and thermal properties.

\subsection{Physicochemical Properties}

Table 1 presents the ultimate, proximate, and calorific fuel properties of BMK in as-received basis (a.r) and compared with similarly ranked coals (Ogala et al., 2012). The results indicate BMK contains $\mathrm{C}, \mathrm{H}, \mathrm{N}, \mathrm{S}, \mathrm{O}$ and $\mathrm{MC}, \mathrm{VM}, \mathrm{AC}$, and $\mathrm{FC}$ as typically found in petroleum coke, biomass, and other coals (Vassilev et al., 2015; Parvez et al., 2017; Nyakuma et al., 2018b).

Table 1: Physicochemical Fuel Properties of BMK Coal

\begin{tabular}{c|c|c|c}
\hline $\begin{array}{c}\text { Elements/ } \\
\text { Fuel Property }\end{array}$ & $\begin{array}{c}\text { Symbol/ } \\
\text { Units }\end{array}$ & $\begin{array}{c}\text { Obomkpa (BMK) } \\
\text { Coal }\end{array}$ & $\begin{array}{c}\text { Ogwashi-Asaba } \\
\text { Coal }\end{array}$ \\
\hline Carbon & C (wt.\%) & 50.47 & 64.30 \\
Hydrogen & H (wt.\%) & 5.66 & 6.50 \\
Nitrogen & N (wt.\%) & 0.58 & 1.10 \\
Sulphur & S (wt.\%) & 0.99 & 4.30 \\
Oxygen & O(wt.\%) & 42.30 & 23.70 \\
Moisture & MC (wt.\%) & 3.80 & 38.00 \\
Volatile Matter & VM (wt.\%) & 53.40 & 55.70 \\
Fixed Carbon & FC (wt.\%) & 26.47 & 29.70 \\
Ash & AC (wt.\%) & 16.38 & 5.60 \\
Higher Heating Value & HHV (MJ/kg) & 19.66 & 16.50 \\
\hline
\end{tabular}

Based on the findings, it can be surmised that BMK contains high contents of $\mathrm{C}, \mathrm{H}$, $\mathrm{O}$ but low compositions of $\mathrm{N}$ and $\mathrm{S}$ in its structure. The calorific analysis showed that BMK has an energy content of $19.66 \mathrm{MJ} / \mathrm{kg}$, hence, it could be classified as lignite A or subbituminous $\mathrm{C}$ ranked 
coal (Speight, 2012). Similarly, the study by Ogala et al. (2012) examined the petrographic, mineralogical and geochemical properties of lignites from Ogwashi-Asaba in the Delta state of Nigeria. The findings showed that the compositions of $\mathrm{C}, \mathrm{H}, \mathrm{N}$, and $\mathrm{S}$ are comparatively higher than BMK examined in this study. However, the somewhat marked differences observed could be to the level of coalification, origins, sampling, treatment or preparation methods of the coals, despite their similar rank and classifications.

Conversely, the proximate properties VM and FC of BMK were found to be in fairly good agreement with Ogala et al. (2012), although the MC and AC were markedly dissimilar. The AC was found to be in good agreement with raw lignite sample examined by Agraniotis et al. (2012). Generally, the observations of this BMK study and the findings in the literature indicate that the mode of sampling, pre-treatment and preparation plays a crucial role in the proximate fuel properties. Lastly, the calorific value of BMK was found to be in fairly good agreement with other lignite coals reported in the literature (Agraniotis et al., 2012; Nyakuma, 2019a; Nyakuma, 2019b).

\subsection{Thermal Properties}

The thermochemical analysis and energy recovery potential of BMK was investigated by thermogravimetric analysis (TGA). The resulting TG, conversion, and DTG plots for the oxidative (combustion) and non-oxidative (pyrolysis) processes are shown in Figures 1-3. 


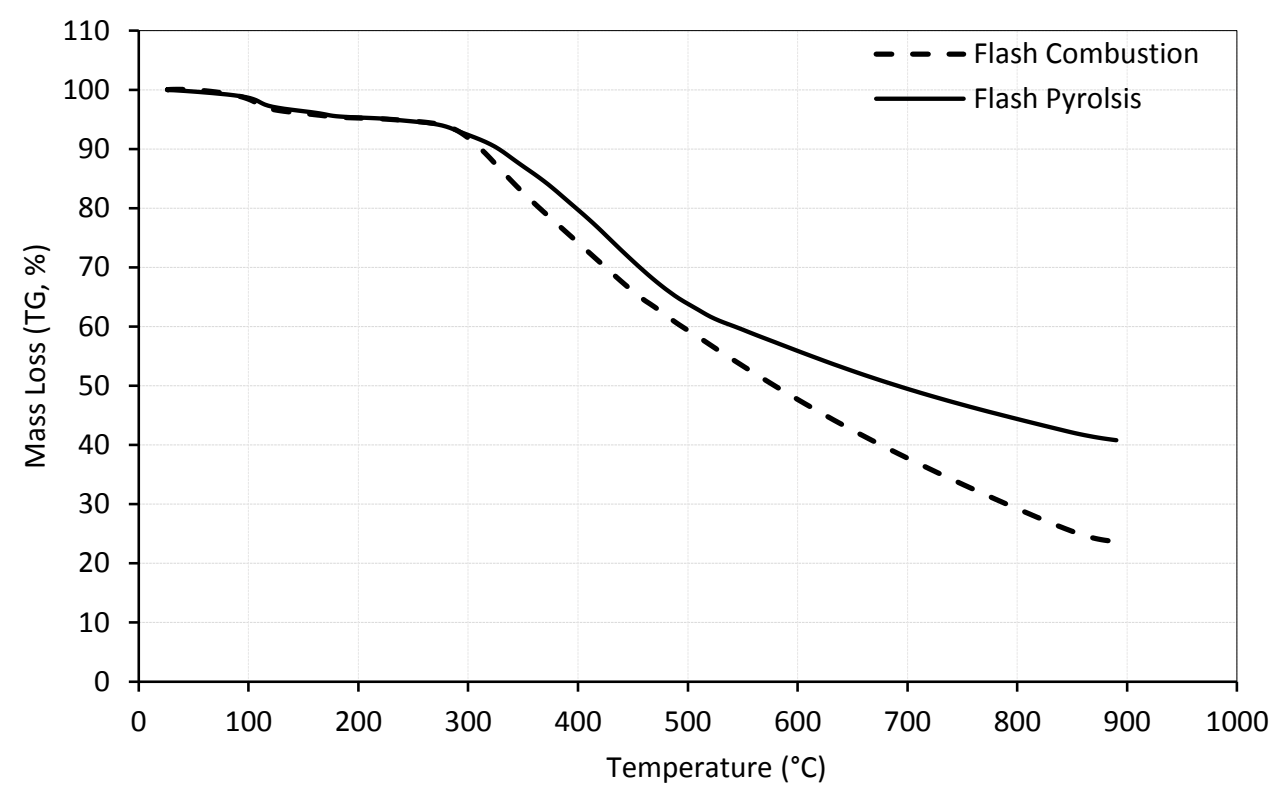

Figure 1: TG Plots for Flash Conversions of BMK Coal

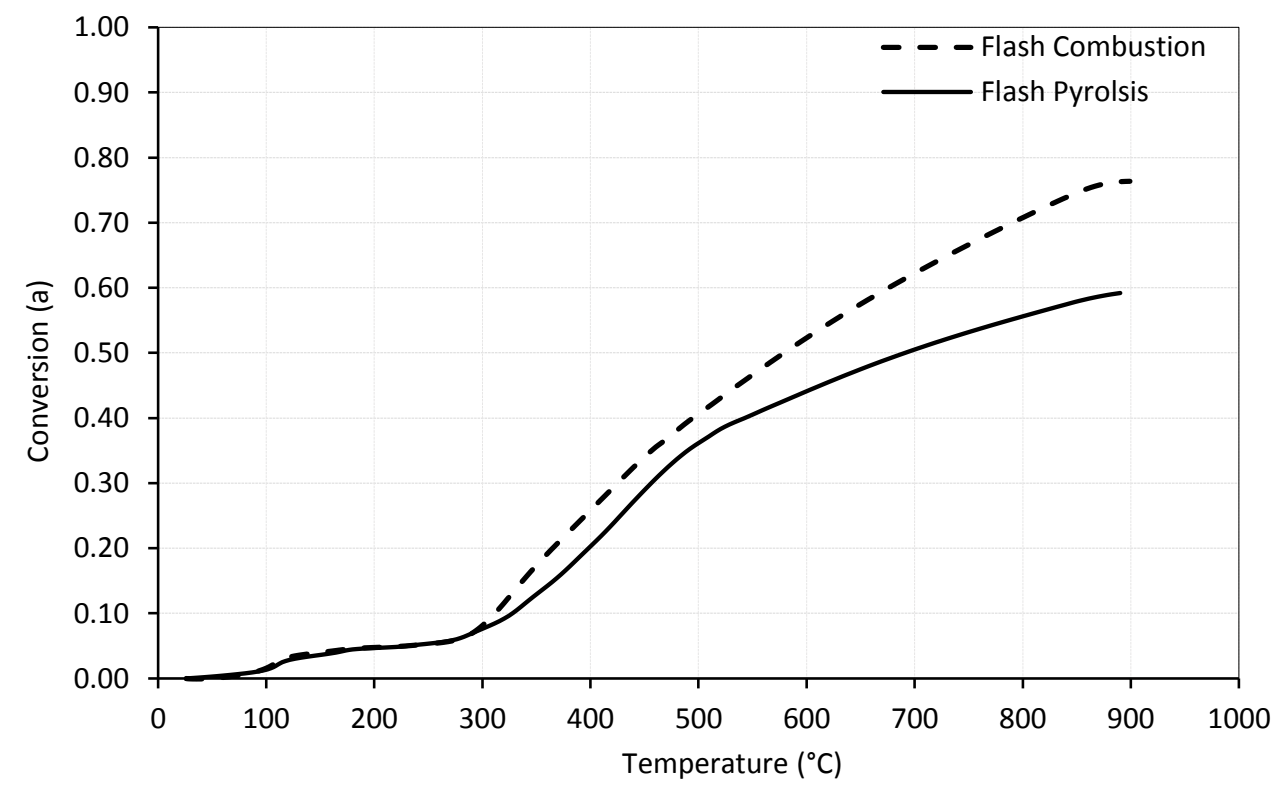

Figure 2: Conversion Plots for Flash Conversions of BMK Coal 
The TG plots indicate BMK coal experienced significant mass loss as evident in the downward sloping plots which can be seen from left to right of Figure 1. The findings indicate the increase in temperature resulted in significant thermal degradation of BMK. Consequently, the rate of conversion (Figure 2) increased with increasing temperature during the process irrespective of the oxidising environment in which the process occurred. Typically, coal degradation is ascribed to the breakdown of the organic matter or macerals (namely; inertinite, vitrinite and liptinite) in the coal structure (Zou et al., 2017). During the process, the inertinite degrades at temperatures below $400{ }^{\circ} \mathrm{C}$, whereas the vitrinite fraction which accounts for the largest thermally degraded component occurs between $450{ }^{\circ} \mathrm{C}$ and $600{ }^{\circ} \mathrm{C}$ (Landais et al., 1989; Xie et al., 2013).

The thermal degradation pathway for BMK was also examined through the DTG plots presented in Figure 3.

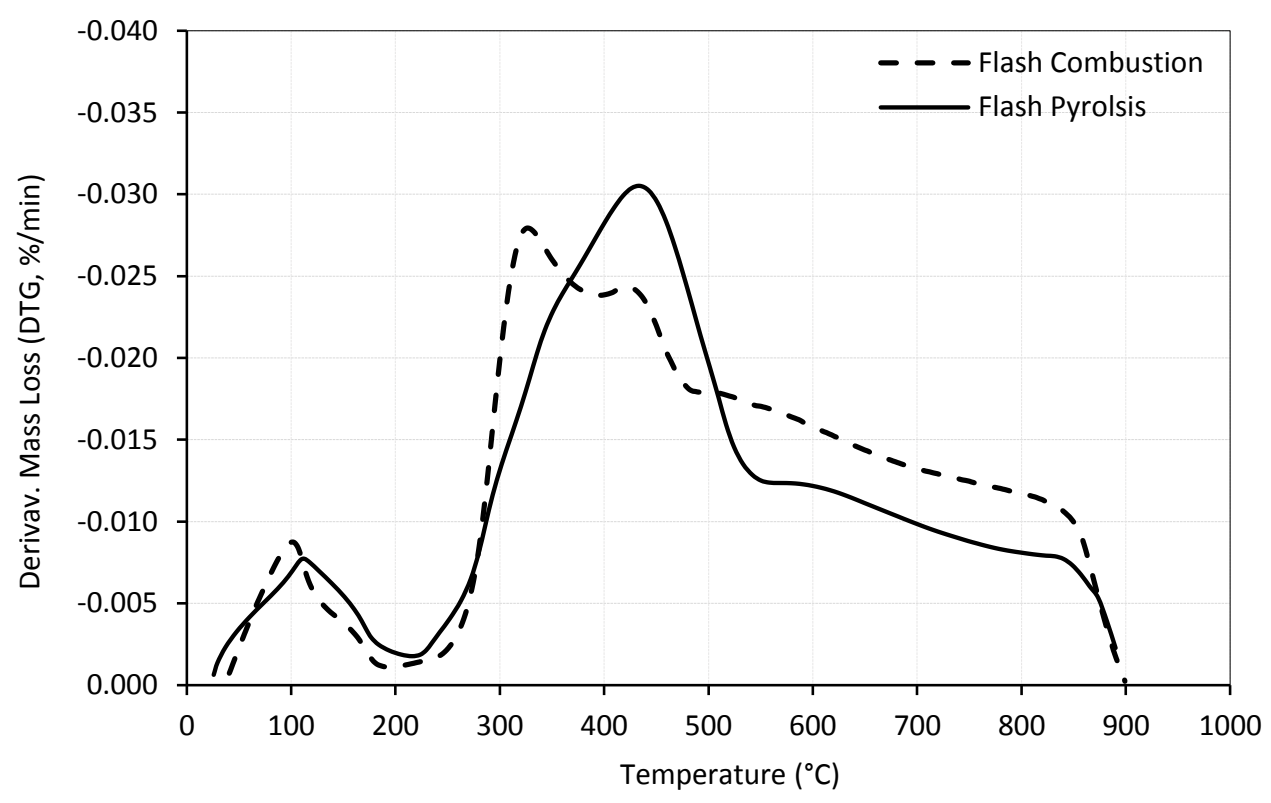

Figure 3: DTG Plots for Flash Conversions of BMK Coal 
As observed, the thermal degradation of BMK resulted in various peaks indicating various reactions or processes occurred under both oxidative and non-oxidative TG conditions. The first set of peaks can be observed in the temperature range from $30{ }^{\circ} \mathrm{C}$ to $200{ }^{\circ} \mathrm{C}$ corresponding to mass losses of $4.72 \%$ and $4.76 \%$ for the oxidative (combustion) and non-oxidative (pyrolysis) processes, respectively. This mass loss observed during the thermal degradation processes is in good agreement with the moisture content $(3.80 \%)$, indicating it could be ascribed to drying or evaporation of surface moisture on BMK.

However, the second set of peaks were observed from $200{ }^{\circ} \mathrm{C}$ to $475{ }^{\circ} \mathrm{C}$ for the oxidative (combustion), which consists of two peaks with maximum values observed at $326.58{ }^{\circ} \mathrm{C}$ and 425 ${ }^{\circ} \mathrm{C}$. For the non-oxidative (pyrolysis) process, the single peak occurred between $200{ }^{\circ} \mathrm{C}$ and 550 ${ }^{\circ} \mathrm{C}$. In comparison, the peaks in the second stage for the oxidative (combustion) process were observably smaller in size and somewhat symmetric compared to the non-oxidative process, which confirms the exothermic and endothermic nature of the degradation processes, respectively.

\subsection{Temperature Profile Characteristics}

The effects of the oxidative (combustion) and non-oxidative (pyrolysis) conditions on the thermal degradation of BMK were examined by temperature profile characteristic (TPC) analysis. Tables 2 and 3 present the TPCs of BMK deduced from the TG and DTG plots, respectively. As observed, the BMK degradation process under oxidative (combustion) conditions resulted in higher mass loss of $76.56 \%$ compared to $59.27 \%$ for the non-oxidative process. This could be ascribed to the exothermic nature of the oxidative process, as earlier reported, which provides higher thermal energy required to degrade the coal maceral components compared to the nonoxidative process. Furthermore, the high mass loss could be ascribed to the higher temperature 
differences observed between the onset and burnout temperatures of both processes. For the oxidative process, the $T_{\text {ons }}$ and $T_{\text {off }}$ occurred between $260.47{ }^{\circ} \mathrm{C}$ and $647.30{ }^{\circ} \mathrm{C}$ indicating a temperature range of $386.83{ }^{\circ} \mathrm{C}$ compared to $306.32{ }^{\circ} \mathrm{C}$ for the non-oxidative process with $T_{\text {ons }}$ and $T_{\text {off }}$ of $295.16^{\circ} \mathrm{C}$ and $601.48^{\circ} \mathrm{C}$, respectively.

Table 2: TG-TPCs for BMK Thermal Degradation under Oxidative and Non-oxidative Conditions

\begin{tabular}{c|c|c|c|c|c}
\hline Process & $\begin{array}{c}\text { Onset Temp. } \\
\left({ }^{\circ} \mathbf{C}\right)\end{array}$ & $\begin{array}{c}\text { Midpoint } \\
\text { Temp. }\left({ }^{\circ} \mathbf{C}\right)\end{array}$ & $\begin{array}{c}\text { Offset Temp. } \\
\left({ }^{\circ} \mathbf{C}\right)\end{array}$ & $\begin{array}{c}\text { Mass Loss } \\
(\%)\end{array}$ & $\begin{array}{c}\text { Residual Mass } \\
(\%)\end{array}$ \\
\hline Combustion & 260.47 & 478.26 & 647.30 & 76.56 & 23.44 \\
Pyrolysis & 295.16 & 438.81 & 601.48 & 59.27 & 40.73 \\
\hline
\end{tabular}

As a result, the residual mass for the non-oxidative process was higher than the oxidative process. Typically, the oxidising environment and the residual mass of the processes is an indicator of the nature of the final products after thermal degradation. For oxidative (combustion) processes, the resulting mass of residuals is largely due to ash residues (Vassilev et al., 2013; Nyakuma et al., 2019). However, since the ash content for BMK is $16.38 \%$ (Table 1), it can be reasonably surmised that the residual mass from the oxidative TG process could also be due in part to coke (7.06\%) along with ash and mineral matter. On the other hand, the residual mass of the nonoxidative process may be largely due to coke (24.35\%) along with ash/ mineral matter. However, extensive coke or carbonization tests are required to empirically confirm the outlined submissions.

The TPCs for the DTG plots were also examined as presented in Table 3. As observed, the thermal degradation processes could be described in terms of drying, devolatilization, and coke degradation/ash formation depending on the oxidising nature of the process. 
Table 3: DTG-TPCs for BMK Thermal Degradation under Oxidative and Non-oxidative Conditions

\begin{tabular}{c|c|c|c|c}
\hline $\begin{array}{c}\text { Thermal } \\
\text { Process }\end{array}$ & $\begin{array}{c}\text { Drying Peak } \\
\text { Temperature }\left({ }^{\circ} \mathbf{C}\right)\end{array}$ & $\begin{array}{c}\text { Peak Drying } \\
\text { Rate }(\% / m i n)\end{array}$ & $\begin{array}{c}\text { Peak } \\
\text { Devolatilization } \\
\text { Temperature }\left({ }^{\circ} \mathbf{C}\right)\end{array}$ & $\begin{array}{c}\text { Peak } \\
\text { Devolatilization } \\
\text { Rate }(\% / m i n)\end{array}$ \\
\hline $\begin{array}{c}\text { Combustion } \\
\text { Pyrolysis }\end{array}$ & 101.17 & 2.91 & 326.58 & 7.60 \\
\hline
\end{tabular}

The results indicate that the peaks for the drying and devolatilization of BMK during the oxidative (combustion) process occurred at lower temperatures compared to the non-oxidative (pyrolysis) process. As earlier surmised, these observations could be ascribed to the higher energy input and exothermic nature of the combustion process, which ensured a higher rate of thermal degradation of BMK coal components. This view is also corroborated by the higher peak drying $(2.91 \% / \mathrm{min})$ and devolatilization $(7.60 \% / \mathrm{min})$ rates observed during the oxidative (combustion) process compared to the non-oxidative process.

Overall, the findings indicate that oxidative (combustion) process is more thermally efficient and could be utilised for future energy recovery or thermal energy applications. However, the nonoxidative (pyrolysis) process could also be beneficial for coke or carbon materials production for various applications such as steel, iron ore or cement production. However, further tests are required to examine the properties of BMK for the proposed applications outlined in these preliminary studies.

\section{Conclusion}

The study presented preliminary findings on the fuel properties and energy recovery potential of Obomkpa (BMK) coal from Delta State in Nigeria. Consequently, the study examined the physicochemical, calorific, and thermal properties of BMK. The ultimate, proximate, and 
calorific value showed that BMK contains high carbon, oxygen, volatile matter, fixed carbon, ash, and higher heating value. Comparison with other coals in the literature indicates BMK may be either lignite or subbituminous ranked coal. The thermal properties indicated the oxidative (combustion) process is a more thermally efficient compared to the non-oxidative (pyrolysis) process. However, further tests are required to examine the fuel properties of BMK for various potential applications such as electric power and production of materials.

\section{Acknowledgements}

The financial, material, and technical support of the Hydrogen and Fuel Cell Laboratory (HFCL) and the University-Industry Research Laboratory (UIRL) both of Universiti Teknologi Malaysia (UTM) along with the National Centre for Petroleum and Coal Research (NCPCR) of Abubakar Tafawa Balewa University are gratefully acknowledged.

\section{References}

Agraniotis, M., Koumanakos, A., Doukelis, A., Karellas, S. and Kakaras, E. (2012). Investigation of Technical and Economic Aspects of Pre-Dried Lignite Utilisation in a Modern Lignite Power Plant Towards Zero Co2 Emissions. Energy, 45(1), 134-141.

Akinyemi, S. A., Adebayo, O. F., Nyakuma, B. B., Adegoke, A. K., Aturamu, O. A., Olaolorun, O. A., Adetunji, A., Hower, J. C., Hood, M. M. and Jauro, A. (2020). Petrology, Physicochemical and Thermal Analyses of Selected Cretaceous Coals from the Benue Trough Basin in Nigeria. International Journal of Coal Science \& Technology, 7(1), 2642. 
Al-Abbas, A. H., Naser, J. and Hussein, E. K. (2013). Numerical Simulation of Brown Coal Combustion in a $550 \mathrm{Mw}$ Tangentially-Fired Furnace under Different Operating Conditions. Fuel, 107, 688-698.

Ayinla, H. A., Abdullah, W. H., Makeen, Y. M., Abubakar, M., Jauro, A., Yandoka, B. M. S. and Abidin, N. S. Z. (2017). Petrographic and Geochemical Characterization of the Upper Cretaceous Coal and Mudstones of Gombe Formation, Gongola Sub-Basin, Northern Benue Trough Nigeria: Implication for Organic Matter Preservation, Paleodepositional Environment and Tectonic Settings. International Journal of Coal Geology, 180, 67-82. BP (2018). BP Statistical Review of World Energy 2017. United Kingdom: British Petroleum.

Cai, J., Xu, D., Dong, Z., Yu, X., Yang, Y., Banks, S. W. and Bridgwater, A. V. (2017). Processing Thermogravimetric Analysis Data for Isoconversional Kinetic Analysis of Lignocellulosic Biomass Pyrolysis: Case Study of Corn Stalk. Renewable and Sustainable Energy Reviews, 82(3), 2705-2715.

Dai, B.-Q., Wu, X., De Girolamo, A. and Zhang, L. (2015). Inhibition of Lignite Ash Slagging and Fouling Upon the Use of a Silica-Based Additive in an Industrial Pulverised CoalFired Boiler. Part 1. Changes on the Properties of Ash Deposits Along the Furnace. Fuel, 139, 720-732.

Denloye, A. O. and Akinola, A. A. (2017). Utilising Clean Coal Technologies for Meeting Nigeria's Energy Needs. NSChE Journal, 32(2), 22-22.

Donahue, C. J. and Rais, E. A. (2009). Proximate Analysis of Coal. Journal of Chemical Education, 86(2), 222.

Iea (2018). Market Report Series: Coal 2018. Paris, France: International Energy Agency. 
Landais, P., Muller, J.-F., Michels, R., Oudin, J.-L. and Zaugg, P. (1989). Comparative Behaviour of Coal and Maceral Concentrates During Artificial Coalification. Fuel, 68(12), 16161619.

Lopez-Velazquez, M. A., Santes, V., Balmaseda, J. and Torres-Garcia, E. (2013). Pyrolysis of Orange Waste: A Thermo-Kinetic Study. Journal of Analytical and Applied Pyrolysis, 99, $170-177$.

Maia, A. A. D. and De Morais, L. C. (2016). Kinetic Parameters of Red Pepper Waste as Biomass to Solid Biofuel. Bioresource Technology, 204, 157-163.

Miller, B. G. (2016). Clean Coal Engineering Technology. Oxford, United Kingdom, ButterworthHeinemann (Elsevier Science).

Musa, D. (2010). The Economics of Electric Power Supply in Nigeria [Online]. Kaduna, Nigeria: Gamji. Available: http://www.gamji.com/article9000/NEWS9075.htm [Accessed 12th April 2020].

Nimmo, W., Daood, S. and Gibbs, B. (2010). The Effect of O2 Enrichment on Nox Formation in Biomass Co-Fired Pulverised Coal Combustion. Fuel, 89(10), 2945-2952.

Nyakuma, B. B. (2016). Physicochemical Characterization and Thermal Analysis of Newly Discovered Nigerian Coals. Bulgarian Chemical Communications, 48(4), 746 - 752.

Nyakuma, B. B. (2019a). Burning Characteristics and Fuel Properties of Obomkpa, Ihioma, and Ogboligbo Lignite Coals from Nigeria. Petroleum \& Coal, 61(2), 262-268.

Nyakuma, B. B., Jauro, A., Oladokun, O., Bello, A., Alkali, H., Modibo, M. and Abba, M. (2018a). Physicochemical, Mineralogical, and Thermogravimetric Properties of Newly Discovered Nigerian Coals. Petroleum \& Coal, 60(4), 641-649. 
Nyakuma, B. B., Jauro, A., Oladokun, O., Uthman, H. and Abdullah, T. (2016). Combustion Kinetics of Shankodi-Jangwa Coal. Journal of Physical Science, 27(3), 1-12.

Nyakuma, B. B., Oladokun, O., Akinyemi, S., Ojoko, E., Jacob, G., Abdullah, T., Alkali, H. and Al-Shatri, A. (2019). Comprehensive Evaluation of the Combustion Kinetic Characteristics of Owukpa Coal. Coke \& Chemistry, 62(8), 371-378.

Nyakuma, B. B., Oladokun, O. and Bello, A. (2018b). Combustion Kinetics of Petroleum Coke by Isoconversional Modelling. Chemistry \& Chemical Technology, 12(4), 505-510.

Nyakuma, B. B. (2019b). Physicochemical, Geomineralogical, and Evolved Gas Analyses of Newly Discovered Nigerian Lignite Coals. Coke \& Chemistry, 62(9), 394-401.

Nyakuma, B. B., Ahmad, A., Johari, A., Tuan, T. A., Oladokun, O. and Aminu, D. Y. (2015). NonIsothermal Kinetic Analysis of Oil Palm Empty Fruit Bunch Pellets by Thermogravimetric Analysis. Chemical Engineering Transactions, 45, 1327-1332.

Nyakuma, B. B., Oladokun, O., Ojoko, E. O., Tanko, B. L. and Jauro, A. (2018c). Physicochemical and Oxidative Thermal Analysis of Nigerian Lignite Coals. Petroleum \& Coal, 60(6), 1207-1215.

Oboirien, B., North, B., Obayopo, S., Odusote, J. and Sadiku, E. (2018). Analysis of Clean Coal Technology in Nigeria for Energy Generation. Energy Strategy Reviews, 20, 64-70.

Ocheri, C. (2017). Revitalization of Coal Development in Nigeria for Industrial Advancement. SFJ Metallurgical Science, 1(2), 1-9.

Odior, A. and Oyawale, F. (2012). A Review of Some of the Operations of Power Holding Company of Nigeria. International Journal of System Assurance Engineering and Management, 3(2), 160-168. 
Odior, A. O. and Omadudu, C. M. (2013). Some Factors Responsible for Erratic Power Supply in Benin City Area of Edo State. International Journal of System Assurance Engineering and Management, 4(1), 48-56.

Ogala, J., Siavalas, G. and Christanis, K. (2012). Coal Petrography, Mineralogy and Geochemistry of Lignite Samples from the Ogwashi-Asaba Formation, Nigeria. Journal of African Earth Sciences, 66, 35-45.

Ogala, J. E. (2018). Geochemistry of Coal and Coal Bearing Strata from the Upper Cretaceous Mamu Formation, Southeastern Nigeria: Implications for Paleoredox History. FUW Trends Science Technology Journal, 3(2B), 787-796.

Oseni, M. O. (2011). An Analysis of the Power Sector Performance in Nigeria. Renewable and Sustainable Energy Reviews, 15(9), 4765-4774.

Oyedepo, S. O. (2014). Towards Achieving Energy for Sustainable Development in Nigeria. Renewable and Sustainable Energy Reviews, 34, 255-272.

Parvez, A. M., Hong, Y., Lester, E. and Wu, T. (2017). Enhancing the Reactivity of Petroleum Coke in Co2 Via Co-Processing with Selected Carbonaceous Materials. Energy \& Fuels, 31(2), 1555-1563.

Speight, J. G. (2012). The Chemistry and Technology of Coal. (Third Edition ed). USA, CRC Press.

Speight, J. G. (2013). Coal-Fired Power Generation Handbook. The United States of America, John Wiley \& Sons.

Vassilev, S. V., Baxter, D., Andersen, L. K. and Vassileva, C. G. (2013). An Overview of the Composition and Application of Biomass Ash. Part 1. Phase-Mineral and Chemical Composition and Classification. Fuel, 105, 40-76. 
Vassilev, S. V., Vassileva, C. G. and Vassilev, V. S. (2015). Advantages and Disadvantages of Composition and Properties of Biomass in Comparison with Coal: An Overview. Fuel, $158,330-350$.

Xie, W., Stanger, R., Lucas, J., Wall, T. and Mahoney, M. (2013). Coal Macerals Separation by Reflux Classification and Thermo-Swelling Analysis Based on the Computer-Aided Thermal Analysis. Fuel, 103, 1023-1031.

Zou, C., Ma, C., Zhao, J., Shi, R. and Li, X. (2017). Characterization and Non-Isothermal Kinetics of Shenmu Bituminous Coal Devolatilization by Tg-Ms. Journal of Analytical and Applied Pyrolysis, 127, 309-320. 